\title{
Evaluation of a vector-control strategy of haemorrhagic thelohanellosis in carp, caused by Thelohanellus hovorkai (Myxozoa)
}

\author{
Yasoja S. Liyanage, Hiroshi Yokoyama*, Hisatsugu Wakabayashi \\ Department of Aquatic Bioscience, Graduate School of Agricultural and Life Sciences, The University of Tokyo, Yayoi 1-1-1, \\ Bunkyo, Tokyo 113-8657, Japan
}

\begin{abstract}
The life cycle of Thelohanellus hovorkai (Myxozoa), the causative agent of haemorrhagic thelohanellosis of carp Cyprinus carpio, involves the alternate oligochaete host Branchiura sowerbyi, which plays the role of vector in the parasite's transmission. Field investigations in carp farms suggested that oligochaete fauna were closely associated with the substrate type of the pond. The pond bottom in the enzootic farm consisted of clay soil and soft sediments comprised of organic mud, in which $B$. sowerbyi dominated in high densities, with a maximum of 5.6 ind. $\mathrm{kg}^{-1}$ soil. In another case, in a carp farm with no previous history of the disease, the pond bottom was sandy soil, in which small-sized oligochaetes, composed mainly of Limnodrilus socialis, dominated. Laboratory studies on the substrate preference of oligochaetes proved that $B$. sowerbyi prefers mud to sand, whereas $L$. socialis has no tendency to substrate tropism. The delicate body surface of $B$. sowerbyi was subject to damage by rugged-edged sand particles, which inflicted severe injuries to the worms. Transmission experiments showed that $L$. socialis, which are non-susceptible to $T$. hovorkai, suppressed the production of $T$. hovorkai actinospores in B. sowerbyi in a mixed assemblage of oligochaetes. Field and experimental evidence in this study imply that substrate replacement in culture ponds might regulate the benthic oligochaete communities, resulting in minimization of the impact of haemorrhagic thelohanellosis. We propose that ecological control of oligochaete fauna by environmental management is a promising strategy against myxozoan diseases.
\end{abstract}

KEY WORDS: Thelohanellus hovorkai - Common carp · Cyprinus carpio · Branchiura sowerbyi · Vector control $\cdot$ Myxosporean · Actinosporean

\section{INTRODUCTION}

A new disease of adult coloured carp Cyprinus carpio (koi carp) characterized by extensive haemorrhages on the body surface first emerged in Niigata Prefecture, Japan, in 1994. The causative organism was identified as a myxozoan parasite, Thelohanellus hovorkai, and the disease was designated as haemorrhagic thelohanellosis (Yokoyama et al. 1998). Histopathological examination indicated that mature spores of $T$. hovorkai dispersed from the plasmodia into the neighboring tissues probably causes the destruction of capillary networks, which results in haemorrhage and edema in the skin lesion (Yokoyama et al. 1998). The life cycle of $T$. hovorkai was elucidated to involve an aurantiactinomyxon-type actinosporean developing in the alternate oligochaete host Branchiura sowerbyi, a large-sized tubificid worm (Yokoyama 1997, Szekely et al. 1998). Subsequently, the identity of myxosporean and actinosporean stages of T. hovorkai was confirmed at the molecular level (Anderson et al. 2000). High prevalence of actinosporean infection in B. sowerbyi was suggested to be one of the etiological factors responsible for the disease outbreak (Yokoyama et al. 1998). Further, Liyanage et al. (1998) demonstrated that massive ingestion of $B$. sowerbyi infected with the actinosporean has an immense role in the onset of the disease, regardless of the strain of host (coloured carp or common carp). 
The antibiotic fumagillin has been described as an efficacious chemotherapeutant against myxozoan diseases, including haemorrhagic thelohanellosis (Yokoyama et al. 1999). However, to date, fumagillin treatment has not been practiced in aquaculture as there are unresolved problems with toxic side-effects to host fish, and the withdrawal time of the drug. Thus, alternative strategies are required for controlling myxozoan diseases. In the present study, we aim to evaluate a novel control strategy for reducing the habitat of an alternate oligochaete host in order to minimize the impact of haemorrhagic thelohanellosis.

\section{MATERIALS AND METHODS}

Substrate type, oligochaete density and actinosporean infection at carp farms (field investigation). From June 1996 to June 1999, epidemiological investigations of Thelohanellus hovorkai infections were conducted in a coloured carp farm in Niigata Prefecture, Japan. Due to repeated outbreaks of haemorrhagic thelohanellosis on this farm during the previous $2 \mathrm{yr}$ (1994 and 1995), the fish farmer discouraged the commercial farming of coloured carp in the following years. Thus, fish were subsequently reared on a small scale for experimental purposes. Each year a new generation of fingerlings was stocked in the pond. In 1996, 1 and 2 yr old coloured carp were kept for a field trial of the fumagillin treatment. In this year, haemorrhagic thelohanellosis occurred again and the prevalence of infection with T. hovorkai reached $100 \%$ (Yokoyama et al. 1999). From 1997 to 1999, 0 yr carp fry were stocked in the pond to monitor the parasite. During the $4 \mathrm{yr}$ study period (1996 to 1999), benthic samples were collected from the pond bottom with a small shovel and washed with a hand-net with $2 \mathrm{~mm}$ openings. Materials retained on the net were placed in a tray, and oligochaete worms were isolated. Oligochaete identification was based on visual and microscopic examinations of the posterior gill filaments (for Branchiura sowerbyi) and the characteristics of the chaetae. The density of oligochaetes in the pond was enumerated by counting the number of worms in $1 \mathrm{~kg}$ soil samples, randomly selected from 10 different areas of the pond. Prevalence of actinosporean infection was determined according to Yokoyama et al. (1991); briefly, oligochaete worms were individually placed in 24-well plates filled with $2 \mathrm{ml}$ dechlorinated tap water, and waterborne actinospores were observed by inverted phase-contrast microscopy.

Similar surveys were conducted on a common carp farm with no previous history of the disease, in Ibaraki Prefecture, Japan. From June to September 2000, benthic samples were collected from a fry pond, and oligochaete densities and actinosporean infections were determined as described above.

Substrate preference of oligochaetes (laboratory investigation). To prepare naïve oligochaete worms, Branchiura sowerbyi and Limnodrilus socialis were collected from a goldfish farm in Saitama Prefecture and transported to our laboratory at the University of Tokyo. Oligochaetes were separated and placed in 24well plates to check the actinosporean infection described above. Substrate material was brought from a common carp farm in Ibaraki Prefecture, and separated into 3 different sizes by filtration through consecutive steel sieves (JIS style screen set). Mud was classified as very fine silt and clay which passed through the sieve openings of $149 \mu \mathrm{m}$. Fine sand was defined as particles trapped on the $149 \mu \mathrm{m}$ sieve but which passed through the $500 \mu \mathrm{m}$ sieve openings. Coarse sand was classified as particles trapped on the $500 \mu \mathrm{m}$ sieve. Prior to use, all 3 substrates were heated at $70^{\circ} \mathrm{C}$ for $1 \mathrm{~h}$. A 11 plastic square container was divided into 2 compartments; one side was filled with mud and the other side with fine or coarse sand. Forty B. sowerbyi or 40 L. socialis were placed in the centre of each container. After 1 or $3 \mathrm{~h}$, or $1 \mathrm{~d}$, the number of oligochaetes were counted in each area to evaluate the substrate preference.

Transmission experiments. Actinosporean-free Branchiura sowerbyi and Limnodrilus socialis were selected after actinosporean examination for 10 consecutive days prior to the experiment. A mud layer, $3 \mathrm{~cm}$ thick, was placed as a bottom substrate in 11 plastic containers. Fifty B. sowerbyi and 50 L. socialis were separately reared in containers (single-species culture groups). Fifty B. sowerbyi were mixed with 50 L. socialis and transferred to a third container (a mixed-culture group) and allowed to settle for $1 \mathrm{~d}$. The same sets of experiments were done with coarse sand as the bottom substrate. T. hovorkai myxospores were harvested from minced tissues of experimentally infected common carp, and added to each container at a concentration of $5 \times 10^{5}$ spores ind. ${ }^{-1}$. All containers were maintained at $20^{\circ} \mathrm{C}$, and continuously supplied with gentle aeration. Actinospores released into the water column were collected by filtration using a nylon mesh with openings of $20 \mu \mathrm{m}$, and the number of spores released per day was determined, until no spores were detected.

\section{RESULTS}

\section{Field investigations at carp farms}

During the 4 yr study period at the coloured carp pond in Niigata Prefecture, Thelohanellus hovorkai 
Table 1. Densities of Branchiura sowerbyi and prevalences of actinosporean infection in the colored-carp farm enzootic for haemorrhagic thelohanellosis, Niigata Prefecture, Japan. nd: not determined

\begin{tabular}{|lcc|}
\hline $\begin{array}{l}\text { Sampling } \\
\text { date }\end{array}$ & $\begin{array}{c}\text { Density of } \\
\text { B. sowerbyi } \\
\text { (ind. } \text { kg }^{-1} \text { soil) }\end{array}$ & $\begin{array}{c}\text { Prevalence of } \\
\text { actinosporean } \\
\text { infection (\%) }\end{array}$ \\
\hline June 1996 & 5.4 & $80.8^{\mathrm{a}}$ \\
July 1996 & 1.9 & $60.7^{\mathrm{a}}$ \\
May 1997 & nd & 44.0 \\
August 1998 & 3.2 & 4.0 \\
November 1998 & 5.6 & 0.2 \\
April 1999 & 0.5 & 5.0 \\
June 1999 & nd & 92.0 \\
aData cited from Yokoyama et al. (1998) & \\
\hline
\end{tabular}

infections persisted in fish and oligochaete hosts. The pond bottoms consisted of clay soil and soft sediments comprising mud and decomposing organic matter, in which Branchiura sowerbyi dominated. Densities of $B$. sowerbyi were 1.9 to 5.6 ind. $\mathrm{kg}^{-1}$ soil during 1996 and 1998, but decreased to 0.5 ind. $\mathrm{kg}^{-1}$ soil in April 1999 (Table 1). Prevalences of the T. hovorkai actinosporean fluctuated among sampling months, but peaked in June, with values of 80.8 and $92.0 \%$ in 1996 and 1999, respectively.

In the common carp farm with no previous history of the disease, in Ibaraki Prefecture, the bottom of the pond was sandy soil, and no Branchiura sowerbyi were found. Small-sized oligochaetes consisting of Limnodrilus socialis and Tubifex sp. dominated, and their densities were as high as 5.3 ind. $\mathrm{kg}^{-1}$ soil in June 2000 (Table 2). Neither T. hovorkai myxospores nor the actinosporean were detected in the fish or oligochaete hosts.

\section{Substrate preference of oligochaetes}

After $1 \mathrm{~h}$ of beginning the experiment, 80\% (32/40 worms) of Branchiura sowerbyi actively moved towards the mud compartment, and after $1 \mathrm{~d}$ ca. $90 \%$ (36/40 worms) were found in the mud compartment. On the other hand, Limnodrilus socialis did not exhibit a remarkable habitat preference after $1 \mathrm{~h}$, or even after $3 \mathrm{~h}_{\text {; }}$ $60 \%$ (24/40 worms) of them still remained at the boundary. After $1 \mathrm{~d}$, distribution rates of L. socialis were 60 and $40 \%$ in mud and coarse sand, respectively (Fig. 1). In the other experiment, using mud and fine sand as substrates, the movement pattern of oligochaetes was similar to that described above (data not shown). Almost

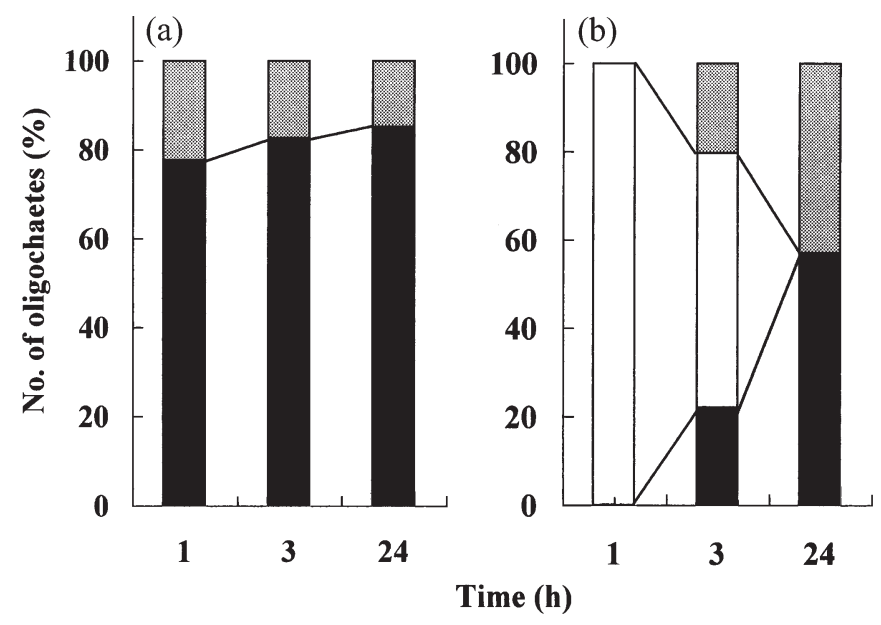

Fig. 1. Substrate preference of (a) Branchiura sowerbyi and (b) Limnodrilus socialis placed in a choice-test between 2 types of substrate. Black, gray, and white columns show the distribution of the oligochaetes in mud, coarse sand, and on the boundary between the two, respectively

all B. sowerbyi reared in mud were healthy (Fig. 2), whereas most of the worms reared in sand were severely injured on the body surface, and in some cases even died (Fig. 3). No physical damage on $L$. socialis was found in any substrates.

\section{Experimental production of actinosporeans in oligochaetes}

At 80 to $90 \mathrm{~d}$ post-exposure, high numbers (maximum of ca. 15000 spores $\mathrm{d}^{-1}$ ) of waterborne actinospores were released from Branchiura sowerbyi in the single-species culture placed in mud, whereas spore release was remarkably reduced (maximum of ca. 2000 spores $\mathrm{d}^{-1}$ ) and delayed in the mixed-species group (Fig. 4). Sand-reared oligochaete groups yielded a lower production of actinospores. Spore release from $B$. sowerbyi in the single-species culture in sand was suppressed (maximum of ca. 2200 spores $\mathrm{d}^{-1}$ ), and no

Table 2. Densities of Branchiura sowerbyi oligochaetes and prevalences of actinosporean infection in the common carp farm with no history of haemorrhagic thelohanellosis, Ibaraki Prefecture, Japan. Small-type oligochaetes are mainly Limnodrilus socialis, and rarely Tubifex sp.

\begin{tabular}{|lccc|}
\hline $\begin{array}{l}\text { Sampling } \\
\text { date }\end{array}$ & $\begin{array}{c}\text { Density of } \\
\text { B. sowerbyi } \\
\text { (ind. kg-1 } \text { soil) }\end{array}$ & $\begin{array}{c}\text { Density of small- } \\
\text { type oligochaetes } \\
\text { (ind. } \mathrm{kg}^{-1} \text { soil) }\end{array}$ & $\begin{array}{c}\text { Prevalence of } \\
\text { actinosporean } \\
\text { infection (\%) }\end{array}$ \\
\hline June 2000 & 0 & 5.3 & 0 \\
July 2000 & 0 & 0.3 & 0 \\
September 2000 & 0 & 1.2 & 0 \\
\hline
\end{tabular}




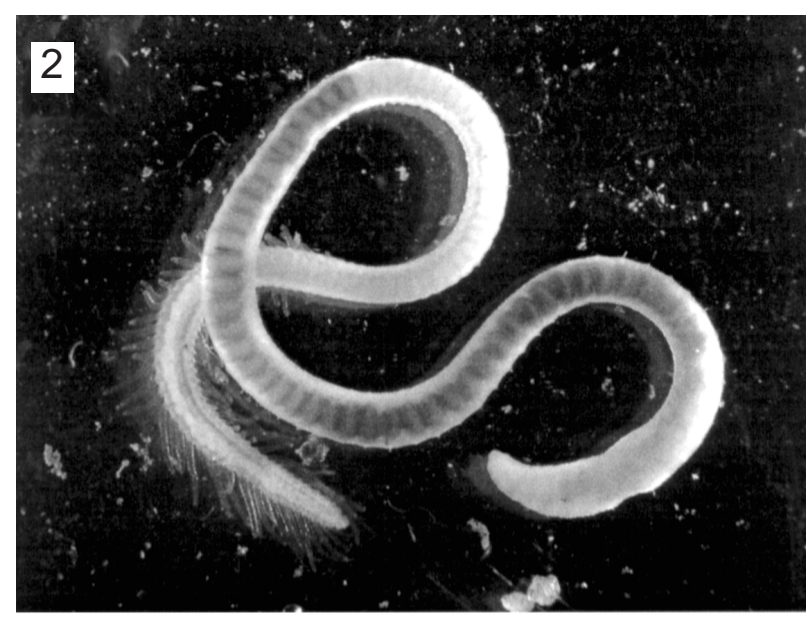

3

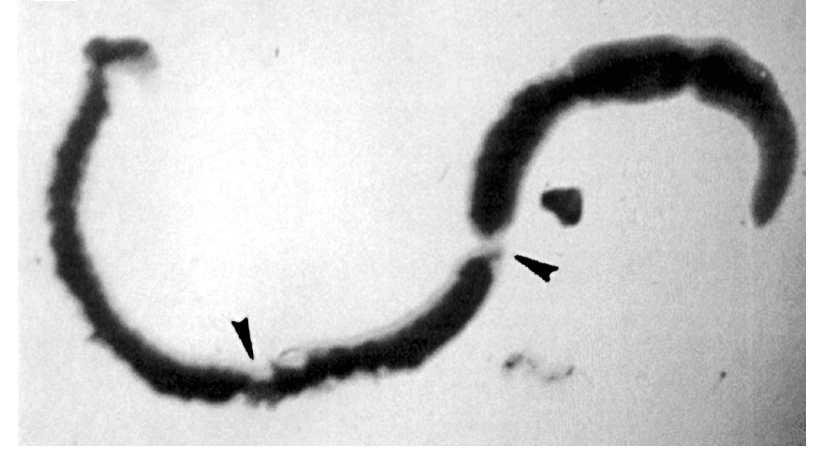

Figs. 2 \& 3. Branchiura sowerbyi. Fig. 2. Appearance of an individual reared in mud. Fig. 3. Appearance of an individual reared in coarse sand. Note severe injuries (arrows) on the body surface

actinospores were produced in the mixed-species culture group in sand. Limnodrilus socialis remained uninfected in any group.

\section{DISCUSSION}

The field surveys suggest that oligochaete fauna were closely associated with the substrate characteristics of the pond, and the laboratory experiments proved that Branchiura sowerbyi strongly preferred mud to sand. Further, Yokoyama et al. (2002) found that the cumulative mortality of $B$. sowerbyi reared in sand was approximately $60 \%$. It is highly likely that rugged sand particles inflict severe injuries on the delicate body surface of $B$. sowerbyi, while Limnodrilus socialis can survive without any physical damage, probably because they are small enough to slip through sand particles. Habitat preferences of aquatic oligochaetes have been demonstrated in the context of myxozoan epizootiology (Xiao \& Desser 1998). Kopriv- nikar et al. (2002) reported a close association of oligochaete fauna with several environment parameters, including substrate type, texture, nutritional potentials, and anaerobic conditions created by decomposing organic matter. Allen \& Bergersen (2002) indicated that low velocity, standing, or impounded waters, which aggregate and concentrate nutrients and sediments, can create optimum habitats for Tubifex tubifex, which is the alternate oligochaete host for Myxobolus cerebralis, the causative agent of whirling disease.

Combined field and experimental evidence in this study implies that by replacing the bottom substrate of mud with sand, a shift in oligochaete communities from Branchiura sowerbyi-dominant to non-susceptible oligochaetes is feasible, probably resulting in minimization of the haemorrhagic thelohanellosis in carp ponds. However, it is not known why actinosporean production decreased in the mixed assemblages of $B$. sowerbyi and Limnodrilus socialis, compared to the single-species culture of $B$. sowerbyi. It is likely that $L$. socialis inactivate myxospores of Thelohanellus hovorkai, reducing the infective dose to $B$. sowerbyi. In the case of Myxobolus cerebralis, myxospores were in-

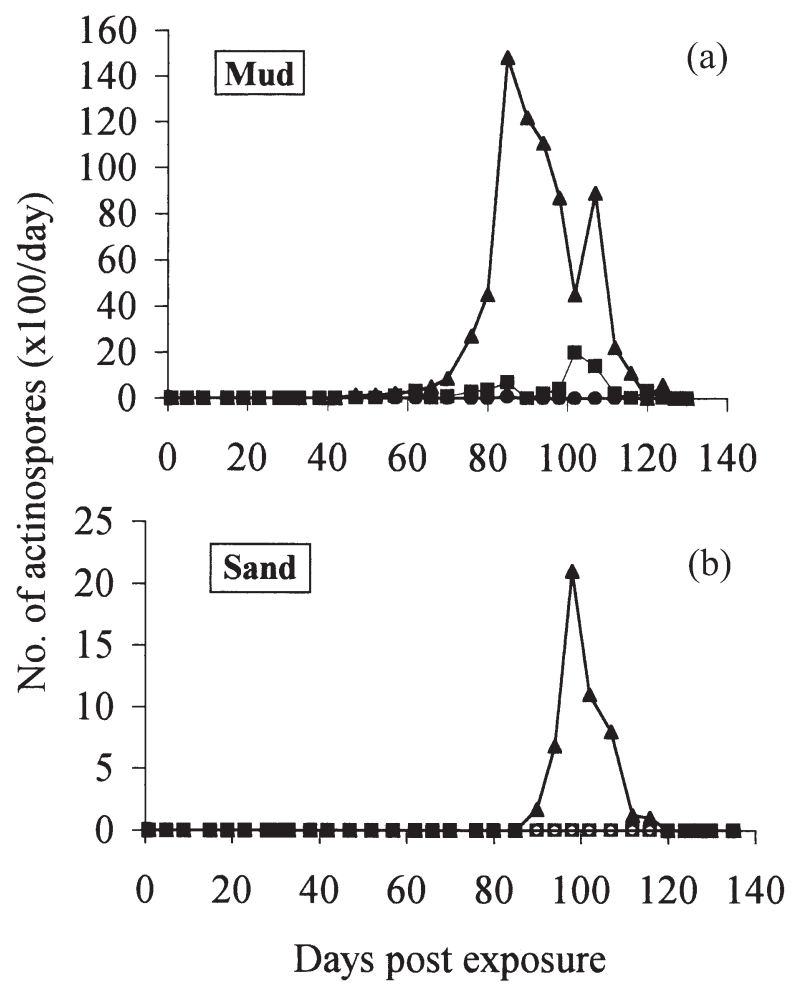

Fig. 4. Production of Thelohanellus hovorkai actinospores from oligochaete populations reared in (a) mud or (b) coarse sand. $\mathbf{\Delta}$ : single-species culture of Branchiura sowerbyi. घ: mixed culture of $B$. sowerbyi and Limnodrilus socialis. -: single-species culture of $L$. socialis 
gested by non-susceptible oligochaetes, polar filaments were extruded, valves opened, and the sporoplasms migrated, but early stages failed to develop in the worms (El-Matbouli et al. 1999). This observation suggests that non-susceptible oligochaete hosts may play a significant role in removing the myxosporean spores in sediments (Hedrick 1998). It is also probable that $L$. socialis could adversely affect feeding conditions of $B$. sowerbyi, resulting in a decrease in spore ingestion by $B$. sowerbyi. Further studies are required to determine how L. socialis suppressed T. hovorkai infection in mixed oligochaete populations.

This is the first report on a potential vector-control strategy in myxozoan diseases. Until now, to develop countermeasures against myxozoan infections, little effort has been dedicated to understanding the ecology of alternate oligochaete hosts, which play the role of vector in transmission of myxozoan parasites. Vector-control strategies have been widely employed for vector-borne human parasitic diseases such as malaria, filariasis and schistosomiasis, e.g. the use of insecticide-treated mosquito nets, the introduction of mosquitofish and the elimination of aquatic vector breeding sites (Ault 1994). These methods have been evaluated as long-term sustainable and environmentally sound in many tropical areas (Molyneux 1998). However, it would be premature to conclude that such a strategy can be extrapolated to other myxozoan diseases, because alternate invertebrate hosts for myxozoans do not always have a strong substrate tropism. Nevertheless, besides substrate adaptability, other biological or ecological factors eliminating the habitat of alternate hosts are worth considering.

In conclusion, we propose that integrated management programmes should be planned for myxozoan diseases. Regarding haemorrhagic thelohanellosis, the following protocol is suggested: (1) risk assessment of disease outbreaks through field investigations of oligochaete fauna and substrate characteristics; (2) regular monitoring of Branchiura sowerbyi abundance, and prevalence of actinosporean infection with Thelohanellus hovorkai; (3) environmental restoration, reducing eutrophication of earthen ponds by removal of organic load, and a soil amendment regulating the oligochaete community from $B$. sowerbyi-dominant to non-susceptible oligochaetes. Alternatively, the biological control of oligochaete abundance using benthoseating fishes is now under trial (Yokoyama et al. 2002).

Acknowledgements. We greatly thank the Niigata Prefectural Inland Freshwater Fisheries Experimental Station for their

Editorial responsibility: Wolfgang Körting,

Hannover, Germany kind cooperation in collection of the materials, and the members of our laboratory for their technical assistance during this study.

\section{LITERATURE CITED}

Allen MB, Bergersen EP (2002) Factors influencing the distribution of Myxobolus cerebralis, the causative agent of whirling disease, in the Cache la Poudre River, Colorado. Dis Aquat Org 49:51-60

Anderson CL, Canning EU, Schafer SM, Yokoyama H, Okamura B (2000) Molecular confirmation of Thelohanellus hovorkai Achmerov, 1960 (Myxozoa: Myxosporea). Bull Eur Assoc Fish Pathol 20:111-115

Ault SK (1994) Environmental management-a reemerging vector control strategy. Am J Trop Med Hyg 50:35-49

El-Matbouli M, Gay M, McDowell TS, Georgiadis MP, Hedrick RP (1999) The potential for using biological control technologies in the management of whirling disease. Proc 5th Annual Whirling Disease Symposium, Montana. The Whirling Disease Foundation, Bozeman, MT p 191-195

Hedrick RP (1998) Whirling disease: re-emergence among wild trout. Immunol Rev 166:365-376

Koprivnikar J, Koehler A, Rodd FH, Desser SS (2002) Environmental factors affecting the distribution and abundance of cyst-forming Myxobolus spp. and their cyprinid hosts in 3 lakes in Algonquin Park, Ontario. J Parasitol 88:467-473

Liyanage YS, Yokoyama H, Matoyama H, Hosoya H, Wakabayashi H (1998) Experimentally induced haemorrhagic thelohanellosis caused by Thelohanellus hovorkai (Myxozoa: Myxosporea). Fish Pathol 33:489-494

Molyneux DH (1998) Vectorborne parasitic diseases - an overview of recent changes. Int J Parasitol 28:927-934

Szekely CS, El-Mansy A, Molnar K, Baska F (1998) Development of Thelohanellus hovorkai and Thelohanellus nikolskii (Myxosporea: Myxozoa) in oligochaete alternate hosts. Fish Pathol 33:107-114

Xiao C, Desser SS (1998) The oligochaetes and their actinosporean parasites in Lake Sasajewun, Algonquin Park, Ontario. J Parasitol 84:1020-1026

Yokoyama H (1997) Transmission of Thelohanellus hovorkai Achmerov, 1960 (Myxozoa: Myxosporea) to common carp Cyprinus carpio through the alternate oligochaete host. Syst Parasitol 36:79-84

Yokoyama H, Ogawa K, Wakabayashi H (1991) A new collection method of actinosporeans - a probable infective stage of myxosporeans to fishes - from tubificids and experimental infection of goldfish with the actinosporean Raabia sp. Fish Pathol 26:133-138

Yokoyama H, Liyanage YS, Sugai A, Wakabayashi H (1998) Hemorrhagic thelohanellosis of color carp caused by Thelohanellus hovorkai (Myxozoa: Myxosporea). Fish Pathol 33:85-89

Yokoyama H, Liyanage YS, Sugai A, Wakabayashi H (1999) Efficacy of fumagillin against haemorrhagic thelohanellosis caused by Thelohanellus hovorkai (Myxozoa: Myxosporea) in colored carp, Cyprinus carpio L. J Fish Dis 22: $243-245$

Yokoyama H, Liyanage YS, Wakabayashi H (2002) A new strategy against myxosporean diseases: vector control in hemorrhagic thelohanellosis of cultured carp. Fish Sci 68(Suppl I):825-828

Submitted: November 10, 2002; Accepted: January 30, 2003 Proofs received from author(s): March 25, 2003 